\title{
THE INFLUENCE OF BIOSTIMULANTS ON TOMATO PLANTS CULTIVATED UNDER HYDROPONIC SYSTEMS
}

\author{
Mostafa M. ABDELKADER ${ }^{*}$ (D), Magomed S. GAPLAEV ${ }^{2}$, Aslambek A. TEREKBAEV ${ }^{2}$, \\ Mikhail Y. PUCHKOV ${ }^{3}$ \\ ${ }^{1}$ Sohag University, Faculty of Agriculture, Egypt \\ ${ }^{2}$ Chechen Scientific Research Institute of Agriculture, Russia \\ ${ }^{3}$ Astrakhan State University, Russia \\ Received: December 2020; Accepted: July 2021
}

\begin{abstract}
Two biostimulants, RutfarmMaxifol (Ascophyllum nodosum extract 17.5\%, amino acids, macro- and microelements, Agromaster, Russia) and Radifarm (polysaccharides, glycosides, amino acids, and microelements; Valagro, Italy), were applied at different concentrations on tomato plants of the hybrid cultivar 'Merlice', grown under a hydroponic system. Biostimulants were applied in the form of seed soaking and twice as foliar sprayings at flowering and at the initial fruit development stages. Biostimulants were applied as water solutions at concentrations of $2.5,5.0$, and $7.5 \mathrm{mg} \cdot \mathrm{L}^{-1}$. Plant growth, productivity, and fruit quality parameters were determined at three points: 35, 70, and 105 days after seeding. All biostimulant treatments resulted in higher values of growth parameters and yield productivity in relation to the control. The application of biostimulants improved the parameters of the fruits' quality by increasing the total soluble solids and antioxidants, ascorbic acid, and carotenoid contents but it did not affect tomato fruit acidity; therefore, tomato fruits from the treated plants were tastier than those from control.
\end{abstract}

Key words: fruit quality, fruit yield, growth parameters, Radifarm, RutfarmMaxifol, seaweed

\section{INTRODUCTION}

Sustainable agriculture is a new style of farming that seeks to optimize production technology to obtain long-term stability of the agricultural sector, environmental protection, and human safety through the application of natural substances or microorganisms to enhance plant development, save soil fertility, and produce a healthy product (Robertson \& Harwood 2013). Sustainable agriculture therefore aims to mitigate adverse impacts on farm environments while providing a sustained production and profit level (Fereres \& Villalobos 2016; Corell et al. 2019).

According to the European Council of Biostimulants Industry (EBIC), biostimulants are natural substances or microorganisms that stimulate and enhance nutrient uptake, nutrient efficiency, tolerance to abiotic stresses, and natural processes to plants or the rhizosphere. The biostimulant concept has gained attention in recent years as a potential solution to some of the negative impacts of a changing climate on agriculture (Yakhin et al. 2017).
In line with the EBIC, Maxifol (Agromaster, Russia) is classified as a biostimulant. It contains, as the main active ingredient, seaweed extract. Seaweeds are multicellular, macroscopic organisms found in coastal and marine ecosystems that contain polysaccharides, polyunsaturated fatty acids, enzymes, and bioactive peptides (Shukla et al. 2016; Okolie et al. 2018). Seaweeds can live in extreme conditions, including those of temperature, salinity, and light. Compared to terrestrial organisms, seaweeds generate more stress-related substances, essential for their survival in hostile environment (Shukla et al. 2018). They are a source of plant biostimulants and can be applied to improve agricultural productivity (du Jardin 2015; Oosten et al. 2017). Extracts from Ascophyllum nodosum have been demonstrated to promote plant growth, reduce some biotic and abiotic plant stresses, and increase yield and quality (Shukla et al. 2019). Seaweed extracts are eco-friendly alternatives to the use of synthetic fertilizers and growth regulators (Carvalho et al. 2019). 
Radifarm (Valagro, Italy) is a plant biostimulant containing amino acids, glycosides, saponins, betaines, polysaccharides, organic acids, vitamins, and microelements (Tkalec et al. 2010). Radifarm, applied in the early stages of growth, promotes an extensive root system by speeding up the elongation of lateral roots and producing more adventitious roots (Parađiković et al. 2019; Bulgari et al. 2019).

Biostimulants can enhance plant stress tolerance by means of active components, such as polysaccharides, proteins, amino acids, and glycosides. Simultaneously, plants treated with biostimulants increasingly develop their roots, stems, and leaves, which is necessary for better plant adaptation after transplantation (Zeljković et al. 2010). This study aims to determine the impact of two biostimulants on the growth and yield of tomato plants cultivated in hydroponic system under greenhouse conditions.

\section{MATERIALS AND METHODS}

\section{Growing conditions and plant material}

A greenhouse experiment was conducted with the tomato hybrid cultivar 'Merlice', which is recommended for greenhouse cultivation on artificial substrates (De Ruiter, the Netherlands). The tomato seeds were sown on plastic trays filled with artificial wool substrates and fertilized with a nutrient solution (EC $\left.=2.5 \mathrm{dS} \cdot \mathrm{m}^{-1}, \mathrm{pH} 5.5\right)$. Through six weeks, tomato seedlings were kept in the greenhouse with temperatures from $18{ }^{\circ} \mathrm{C}$ to $22^{\circ} \mathrm{C}$ during the day and from $16{ }^{\circ} \mathrm{C}$ to $18{ }^{\circ} \mathrm{C}$ at night at $60-65 \%$ relative air humidity. The greenhouse was continuously ventilated to avoid plant diseases. Seedlings with 4-5 true leaves were transplanted to the hydroponic system, using mineral wool as a substrate. After setting the seedlings on plastic boxes filled with wool substrate, they were fertilized with $100 \mathrm{ml}$ per plant per day of a Hoagland nutrient solution $\left(0.54 \mathrm{~g} \cdot \mathrm{L}^{-1}\right.$ of $\mathrm{KNO}_{3}, 0.84 \mathrm{~g} \cdot \mathrm{L}^{-1}$ of $\mathrm{Ca}\left(\mathrm{NO}_{3}\right)_{2}, 0.14 \mathrm{~g} \cdot \mathrm{L}^{-1}$ of $\mathrm{KH}_{2} \mathrm{PO}_{4}, 0.25 \mathrm{~g} \cdot \mathrm{L}^{-1}$ of $\mathrm{MgSO}_{4}$, and $0.2 \mathrm{~g} \cdot \mathrm{L}^{-1}$ of $\mathrm{Fe}$ ). In the vegetative phase, the EC of the nutrient solution was $3.5 \mathrm{dS} \cdot \mathrm{m}^{-1}$, and in the flowering phase, it was $5.0 \mathrm{dS} \cdot \mathrm{m}^{-1} ; \mathrm{pH}$ was adjusted weekly to $\mathrm{pH} 5.0$ 5.5. The light was set for 16 hours with an intensity of $500 \mu \mathrm{mol} \cdot \mathrm{m}^{-2} \cdot \mathrm{s}^{-1}$ and temperature at $25^{\circ} \mathrm{C}$ day/night, with $60-65 \%$ relative humidity.

\section{Biostimulant treatments}

The experiment was conducted as a completely randomized process, with three replications per treatment and 50 plants per replication. Ten plants of the replicate were taken for analysis of growth parameters. The following concentrations of each biostimulant were studied: Maxifol (MF 2.5, SW 5.0, and $7.5 \mathrm{mg} \cdot \mathrm{L}^{-1}$ ) and Radifarm (RF 2.5, 5.0, and $7.5 \mathrm{mg} \cdot \mathrm{L}^{-1}$ ). They were applied three times: for soaking seeds before seeding and spraying in a volume of $65 \mathrm{ml}$ per plant at the flowering and early fruit development stages. The control plants were sprayed with water. Tomato seeds were soaked in biostimulant solutions for 30 minutes before seeding, while control seeds were soaked in distilled water for the same time.

\section{Biometric parameters}

Biometric parameters of 30 plants per treatment were each analyzed three times: before transplanting seedlings, at fruit set, and at fruit formation phase (35, 70, and 105 days after seeding, respectively). The following parameters were scored: root length (only at transplanting), the plant height, number of the leaves per plant, total leaf area per plant, and fresh and dry weights calculated by multiple average leaf area and number of leaves per plant. The dry weight of whole plants was obtained after washing with deionized water and drying in an oven at $60{ }^{\circ} \mathrm{C}$ for more than 48 hours (10 samples per replicate). The average leaf area was measured using the Image J program as described by Abdelkader et al. (2019a). The relative growth rate (RGR) was calculated according to the formula: $\mathrm{RGR}=\left(\ln W_{2}-\ln W_{1}\right) /\left(t_{2}-t_{1}\right)$, and expressed as $\mathrm{g} \cdot \mathrm{g}^{-1} \cdot$ week $^{-1}$. The crop growth rate (CGR) is the total dry matter produced per plant over a period of time. It was calculated by the following formula: $C G R=\left(\mathrm{W}_{2}-\mathrm{W}_{1}\right) /\left(\mathrm{t}_{2}-\mathrm{t}_{1}\right)$, where $W_{1}=$ dry weight of the plant at time $t_{1}$, and $W_{2}=$ dry weight of the plant at time $t_{2}$ and expressed as $\mathrm{g} \cdot$ week $^{-1}$. plant $^{-1}$. The net assimilation rate (NAR) was measured using the following equation: NAR = $\left(\mathrm{W}_{2}-\mathrm{W}_{1}\right)\left(\ln \mathrm{L}_{2}-\ln \mathrm{L}_{1}\right) /\left(\mathrm{t}_{2}-\mathrm{t}_{1}\right)\left(\mathrm{L}_{2}-\mathrm{L}_{1}\right)$, and expressed as $\left(\mathrm{g} \cdot \mathrm{m}^{-2} \cdot\right.$ week $\left.^{-1}\right)$, where $\mathrm{ln}=$ natural $\mathrm{log}$, $W_{1}=$ dry weight of plant (g) at time $t_{1}$, and $W_{2}=$ dry weight of plant (g) at time $t_{2}$ (Usuda 2004). Yield components were calculated by measuring the following parameters: number of fruits per plant, weight of individual fruit, and fruit yield per plant. 


\section{Biochemical parameters}

Ten tomato fruits at the red-ripening stage were collected from each replicate to conduct biochemical analyses. Three replicates for each treatment and three separate analyses for each replication were conducted. Biochemical properties were evaluated to determine the following parameters: fresh and dry mass of fruit (after drying at $105^{\circ} \mathrm{C}$ ), the titratable acidity (TTA), expressed as a percentage of citric acid by the methods described by the Association of Analytical Communities (Considine 2005), the concentration of ascorbic acid, expressed as $\mathrm{mg} \cdot 100 \mathrm{~g}^{-1}$, determined by the 2,6-dichlorophenolindophenol method, carotenoids (expressed as $\mathrm{mg} \cdot 100 \mathrm{~g}^{-1}$ ), and nitrate $\left(\mathrm{mg} \cdot \mathrm{kg}^{-1}\right.$ ). Sugar to acid ratio (maturity index) was calculated by dividing total soluble solid, measured as ${ }^{\circ}$ Brix using a refractometer, by the titratable acidity of the given samples under analysis as described by Mohammed et al. (1999). The taste index was calculated using the equation of Navez et al. (1999) using the formula: Taste index $=\frac{\text { Brix level }}{20 \text { (acidity) }}+$ acidity.

\section{Statistical analysis}

Data were analyzed using one-way analysis of variance (ANOVA) in a completely randomized design followed by Tukey's HSD test \pm SD $(p=0.05)$ with the help of the MINITAB (v. 19.0) program.

\section{RESULTS}

\section{Biometric parameters}

Soaking tomato seeds in a biostimulator solution before sowing influenced the root length of the seedlings (Fig. 1). Radifarm increased the root length by $4.3-7.8 \%$ and RutfarmMaxifol by $1.2-2.4 \%$ in comparison with the control. The seedlings soaked in Radifarm with a concentration of $7.5 \mathrm{mg} \cdot \mathrm{L}^{-1} \mathrm{had}$ the maximum root length $(7.6 \mathrm{~cm})$. RutfarmMaxifol increased the seedling root length only when it was used at a concentration of $7.5 \mathrm{mg} \cdot \mathrm{L}^{-1}$, but to a lesser extent than Radifarm. Generally, the application of RutfarmMaxifol and Radifarm significantly enhanced growth and other biometric parameters if applied in concentrations of 5 and $7.5 \mathrm{~g} \cdot \mathrm{L}^{-1}$ compared with the control, and the effect increased with concentration (Table 1). RutfarmMaxifol was more effective than Radifarm in the increase of values of the studied parameters.
Figure 2 shows RGR, CGR, and NAR of tomato plants grown under the influence of biostimulants during two periods of growth expressed as weeks after planting (WAP) - the first (5-10 WAP) and second (10-15 WAP). The RGR ranged between 400 and $500 \mathrm{mg} \cdot \mathrm{g}^{-1} \cdot$ week $^{-1}$ at the first growth stage, while in the second growth stage, RGR values decreased to $120-180 \mathrm{mg} \cdot \mathrm{g}^{-1} \cdot$ week $^{-1}$. At the first growth stage, RF 5.0 and RF 7.5 treatments produced the highest RGR, but this effect differed at the second stage. There was a contradictory relationship between RGR values and the age of plants. Generally, RGR declines with increasing plant size (Fig. 2A). Concerning CGR, both biostimulants increased this parameter at the first stage, with a tendency to increase with concentration. At the second growth stage, only Radifarm had the same pattern; the effect of RutfarmMaxifol was different. The concentrations 5 and $7.5 \mathrm{mg} \cdot \mathrm{L}^{-1}$ did not increase this parameter (Fig. 2B). Biostimulants in this experiment stimulated NAR only at the first stage of growth; this parameter in the older plants was not influenced by the biostimulants (Fig. 2C).

\section{Yield components}

For the determination of tomato yield components, the number of fruits per plant (pcs), fruit weight ( $\mathrm{g}$ ), and tomato fruit yield (kg per plant) were measured (Fig. 3). The values of all the above parameters increased with increasing concentration of biostimulators. RutfarmMaxifol was more effective than Radifarm at each concentration. The highest fruit number, fruit weight, and fruit yield gained the highest values at $7.5 \mathrm{~g} \cdot \mathrm{L}^{-1}$ of RutfarmMaxifol. The highest concentrations of biostimulants increased fruit number by 15 (Radifarm) and 20 (RutfarmMaxifol) over the control. The single fruit weight increased at the highest concentrations by $14 \%$ (Radifarm) and $18 \%$ (RutfarmMaxifol). The total yield of the plant increased by $20-70 \%$ when biostimulants were applied.

\section{Biochemical analysis of tomato fruit}

Radifarm enhanced dry matter of tomato fruits from $6.35 \%$ to $6.85 \%$ and RutfarmMaxifol by $6.25-6.45 \%$ (Fig. 4A). The value higher by $14 \%$ over control was obtained with Radifarm $7.5 \mathrm{~g} \cdot \mathrm{L}^{-1}$. The concentrations of total soluble solids (TSSs) and ascorbic acid increased with biostimulator concentration with the same pattern, more with the application of Radifarm (Fig. 4B, C). 
In the present study, the concentration of carotenoids increased significantly only as an effect of the application of 5.0 and $7.5 \mathrm{~g} \cdot \mathrm{L}^{-1}$ of Radifarm (Fig. 4D). The acidity rate tended to decrease as an effect of RutfarmMaxifol treatment, less so in Radifarm treatment. Nitrate concentration in the tomato fruits increased with the concentration of Radifarm by $12 \%$ at $7.5 \mathrm{~g} \cdot \mathrm{L}^{-1}$ (Fig. 4F). Both biostimulants affected maturity degree and taste index in the same way (Fig. 5A, B). Significant increases were obtained at 5.0 and $7.5 \mathrm{~g} \cdot \mathrm{L}^{-1}$, more with the application of Radifarm.

Table 1. Biometric parameters of tomato plants under the influence of biostimulators $\left(\mathrm{mg} \cdot \mathrm{L}^{-1}\right)$ under hydroponic system

\begin{tabular}{|c|c|c|c|c|c|c|c|c|}
\hline $\begin{array}{c}\text { Biometric } \\
\text { parameters }\end{array}$ & $\begin{array}{c}\text { Days after } \\
\text { planting }\end{array}$ & Control & RF 2.5 & RF 5.0 & RF 7.5 & RM 2.5 & RM 5.0 & RM 7.5 \\
\hline \multirow{3}{*}{$\begin{array}{l}\text { Plant } \\
\text { height } \\
(\mathrm{cm})\end{array}$} & & $17.9 \pm 2.0 \mathrm{~d}$ & $18.0 \pm 1.7 \mathrm{~d}$ & $1.2 \pm 2.1 \mathrm{ab}$ & $21.5 \pm 2.3 \mathrm{a}$ & & 20.9 & 21.0 \\
\hline & 70 & $143.5 \pm 5.8 \mathrm{~b}$ & $146.5 \pm 6.6 \mathrm{~b}$ & $171.5 \pm 7.3 \mathrm{a}$ & $178.0 \pm 7.0 \mathrm{a}$ & $159.2 \pm 7.3 \mathrm{ab}$ & $171.0 \pm 5.6 \mathrm{a}$ & $174.0 \pm 6.1 \mathrm{a}$ \\
\hline & & $174.5 \pm 7.9 \mathrm{~d}$ & $180.0 \pm 8.6 \mathrm{~d}$ & $193.5 \pm 9.0 \mathrm{c}$ & $197.5 \pm 10.7 \mathrm{bc}$ & $198.5 \pm 10.3 b c$ & $206.5 \pm 9.4 \mathrm{~b}$ & $217.0 \pm 9.3 \mathrm{a}$ \\
\hline \multirow{3}{*}{$\begin{array}{l}\text { Number } \\
\text { of leaves }\end{array}$} & & $6.5 \pm 0.28 \mathrm{c}$ & $6.8 \pm 0.68 b c$ & $7.2 \pm 0.74 \mathrm{ab}$ & $7.2 \pm 0.35 \mathrm{ab}$ & $6.8 \pm 0.67 \mathrm{bc}$ & $7.3 \pm 0.71 \mathrm{ab}$ & $7.5 \pm 0.80 \mathrm{a}$ \\
\hline & 70 & $32.1 \pm 2.1 \mathrm{~d}$ & $37.1 \pm 1.9 \mathrm{bc}$ & $39.1 \pm 2.6 \mathrm{ab}$ & $40.6 \pm 2.4 \mathrm{a}$ & $35.9 \pm 1.9 \mathrm{c}$ & $37.6 \pm 1.6 \mathrm{bc}$ & $39.0 \pm 2.2 \mathrm{ab}$ \\
\hline & 105 & $43.6 \pm 2.8 \mathrm{c}$ & $50.0 \pm 2.2 \mathrm{bc}$ & $52.4 \pm 2.4 \mathrm{ab}$ & $53.9 \pm 2.2 \mathrm{a}$ & $48.4 \pm 2.2 \mathrm{c}$ & $50.5 \pm 1.8 \mathrm{bc}$ & $52.0 \pm 2.7 \mathrm{ab}$ \\
\hline \multirow{3}{*}{$\begin{array}{l}\text { Plant fresh } \\
\text { weight } \\
\text { (g) }\end{array}$} & 35 & $9.7 \pm 1.0 \mathrm{~d}$ & $9.9 \pm 0.9 \mathrm{~d}$ & $10.7 \pm 1.1 \mathrm{c}$ & $11.7 \pm 1.2 \mathrm{~b}$ & $10.5 \pm 1.0 \mathrm{c}$ & $12.4 \pm 1.2 \mathrm{ab}$ & $13.0 \pm 1.3 \mathrm{a}$ \\
\hline & 70 & $150.7 \pm 7.3 \mathrm{c}$ & $151.1 \pm 8.4 \mathrm{c}$ & $152.8 \pm 6.6 \mathrm{bc}$ & $154.7 \pm 7.9 \mathrm{~b}$ & $154.2 \pm 7.0 \mathrm{bc}$ & $158.9 \pm 8.7 \mathrm{a}$ & $161 \pm 7.2 \mathrm{a}$ \\
\hline & 105 & $201.4 \pm 10.8 \mathrm{c}$ & $216.1 \pm 11.1 b c$ & $230.2 \pm 12.8 \mathrm{~b}$ & $238.7 \pm 12.2 \mathrm{ab}$ & $204.0 \pm 12.0 \mathrm{c}$ & $249.7 \pm 16.9 \mathrm{a}$ & $251.0 \pm 14.3 \mathrm{a}$ \\
\hline \multirow{3}{*}{$\begin{array}{l}\text { Plant dry } \\
\text { weight } \\
\text { (g) }\end{array}$} & & $2.4 \pm 0.1 \mathrm{e}$ & $2.6 \pm 0.3 \mathrm{de}$ & $2.7 \pm 0.2 \mathrm{~cd}$ & $2.8 \pm 0.1 \mathrm{~cd}$ & $2.8 \pm 0.2 \mathrm{bc}$ & $3.1 \pm 0.1 \mathrm{ab}$ & $3.3 \pm 0.2 \mathrm{a}$ \\
\hline & 70 & $19.1 \pm 2.1 \mathrm{~d}$ & $22.1 \pm 2.2 \mathrm{c}$ & $28.8 \pm 2.6 \mathrm{~b}$ & $30.4 \pm 2.7 \mathrm{ab}$ & $24.2 \pm 2.4 \mathrm{c}$ & $30.9 \pm 3.0 \mathrm{ab}$ & $32.0 \pm 1.8 \mathrm{a}$ \\
\hline & 105 & $46.5 \pm 2.7 \mathrm{~d}$ & $55.1 \pm 3.0 \mathrm{c}$ & $58.9 \pm 2.3 \mathrm{~b}$ & $60.3 \pm 3.5 \mathrm{~b}$ & $58.9 \pm 3.3 \mathrm{~b}$ & $73.3 \pm 4.0 \mathrm{a}$ & $75.0 \pm 4.2 \mathrm{a}$ \\
\hline \multirow{3}{*}{$\begin{array}{l}\text { Total leaf } \\
\text { area per } \\
\text { plant } \\
\left(\mathrm{dm}^{2}\right)\end{array}$} & 35 & $0.47 \pm 0.01 \mathrm{c}$ & $0.55 \pm 0.01 \mathrm{bc}$ & $0.59 \pm 0.1 \mathrm{~b}$ & $0.60 \pm 0.02 \mathrm{~b}$ & $0.59 \pm 0.01 \mathrm{~b}$ & $0.73 \pm 0.02 \mathrm{a}$ & $0.75 \pm 0.02 \mathrm{a}$ \\
\hline & 70 & $21.2 \pm 0.68 \mathrm{~b}$ & $23.4 \pm 0.67 \mathrm{a}$ & $24.1 \pm 0.89 \mathrm{a}$ & $23.8 \pm 0.80 \mathrm{a}$ & $23.4 \pm 0.75 \mathrm{a}$ & $23.8 \pm 0.73 \mathrm{a}$ & $23.6 \pm 0.80 \mathrm{a}$ \\
\hline & 105 & $33.2 \pm 1.6 \mathrm{ab}$ & $33.6 \pm 1.3 \mathrm{a}$ & $34.0 \pm 1.8 \mathrm{a}$ & $33.9 \pm 1.9 \mathrm{a}$ & $32.8 \pm 1.7 \mathrm{~b}$ & $33.4 \pm 1.8 \mathrm{a}$ & $34.1 \pm 1.5 \mathrm{a}$ \\
\hline
\end{tabular}

The different lower case letter(s) in each single row indicates significant differences between the treatments at $\mathrm{p}<0.05$ established by Tukey's multiple range test \pm SD

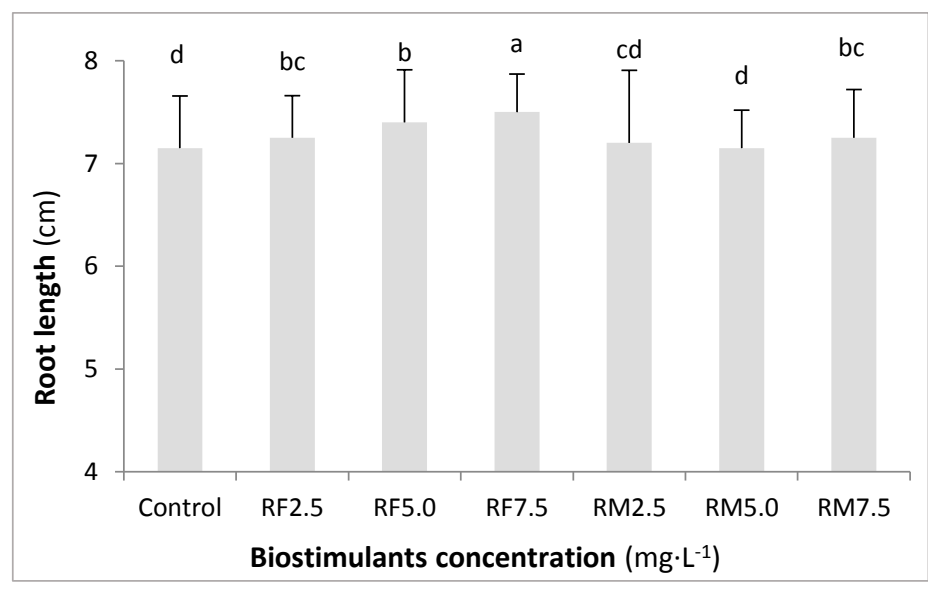

Figure 1. Root length at transplanting (35 days after seeding) of tomato seedlings hybrid cultivar 'Merlice', influenced by seeds soaking in biostimulants Radifarm and RutfarmMaxifol. The different letters indicate significant differences between the treatments at $\mathrm{p}<0.05$ established by Tukey's multiple range test; values represent means \pm SD 


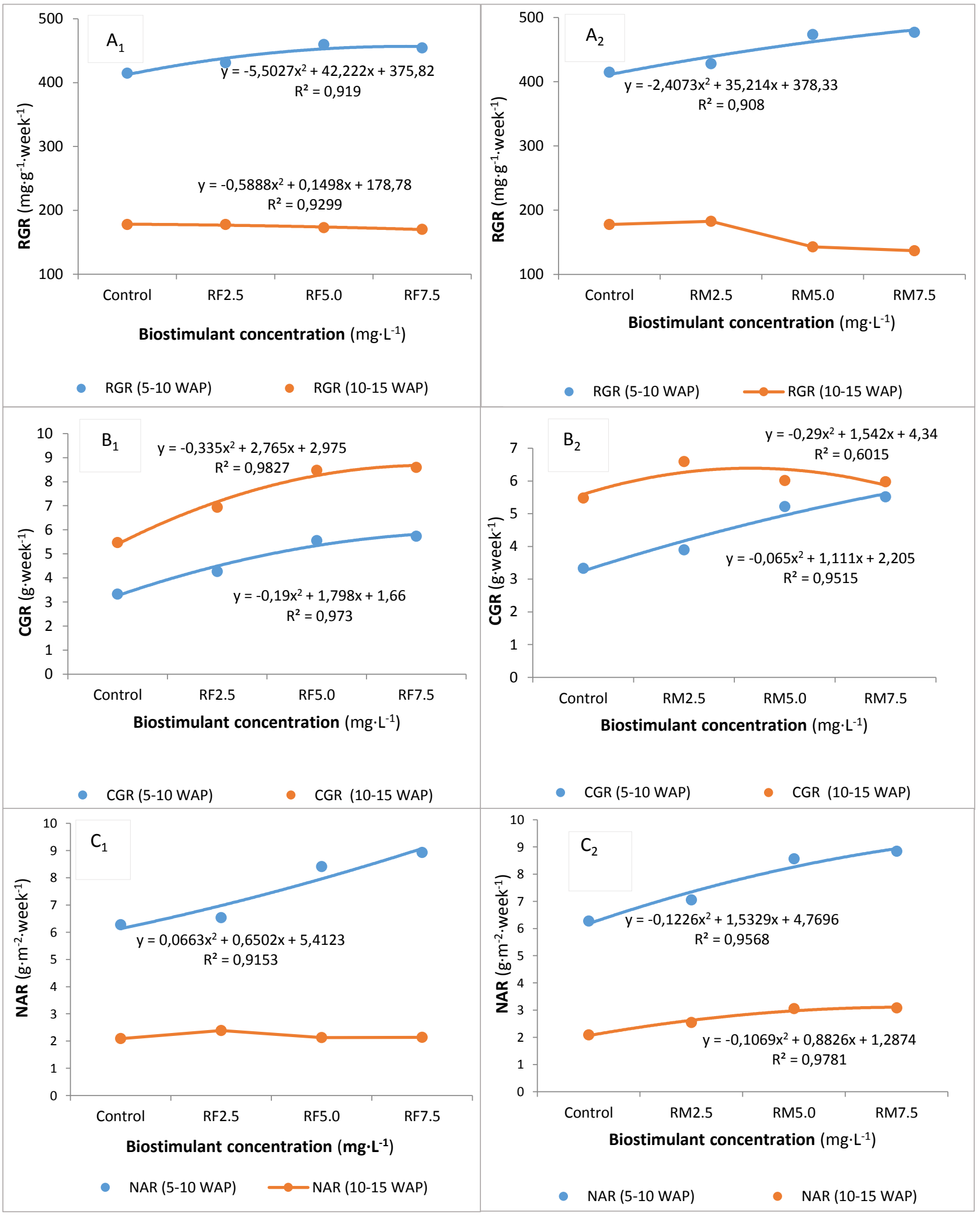

Figure 2. Relative growth rate $\left(A_{1}, A_{2}\right)$, crop growth rate $\left(B_{1}, B_{2}\right)$, and net assimilation rate $\left(C_{1}, C_{2}\right)$ of tomato hybrid cultivar 'Merlice', influenced by biostimulators - Radifarm: RF 2.5, RF 5.0, and RF 7.5; RutfarmMaxifol: SW 2.5, SW 5.0, and SW $7.5+$ control (nontreated) under hydroponic system 

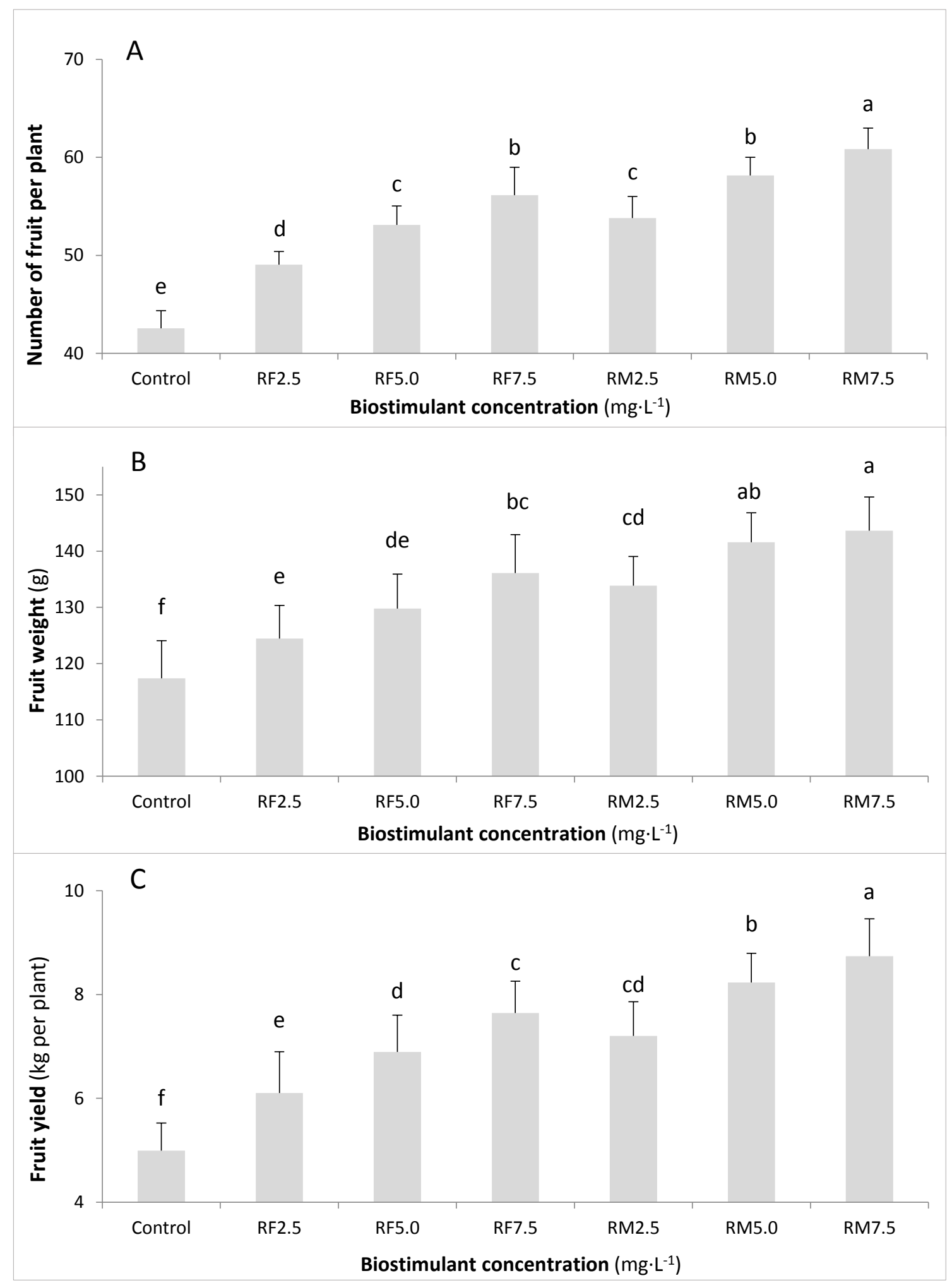

Figure 3. Yield components: number of fruits per plant (A), fruit weight (B), fruit yield (kg per plant) (C) of hybrid cultivar 'Merlice', influenced by biostimulants under hydroponic system. The different lower case letters indicate significant differences between the treatments at $\mathrm{p}<0.05$ established by Tukey's multiple range test; values represent means $\pm \mathrm{SD}$ 


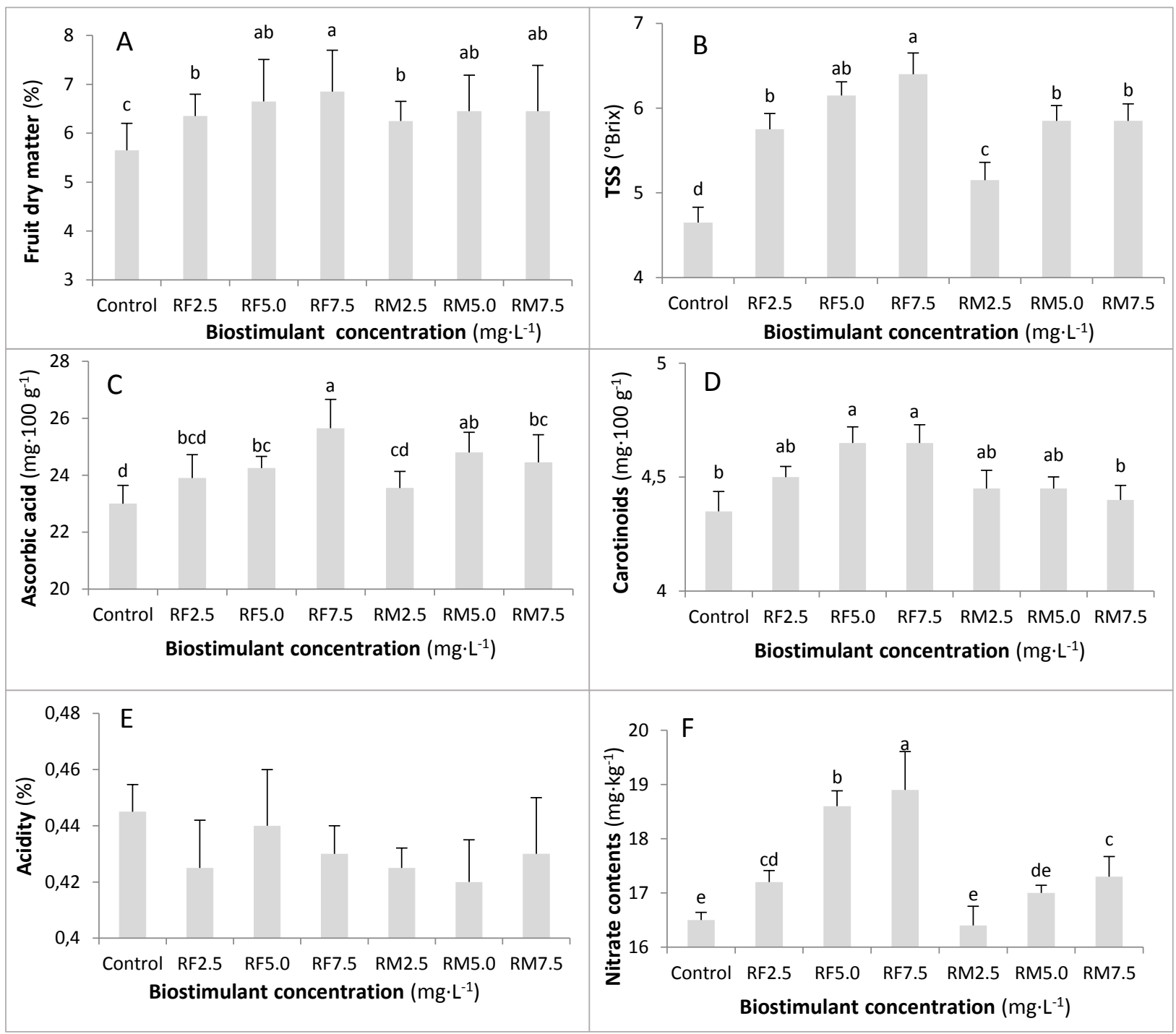

Figure 4. Biochemical parameters: dry matter (A), total soluble solid (B), ascorbic acid (C), carotenoid contents (D), acidity (E), and nitrate contents in tomato fruits hybrid cultivar 'Merlice' (F), influenced by biostimulants under hydroponic system. The different lower case letters indicate significant differences between the treatments at $p<0.05$ established by Tukey's multiple range test; values represent means $\pm \mathrm{SD}$

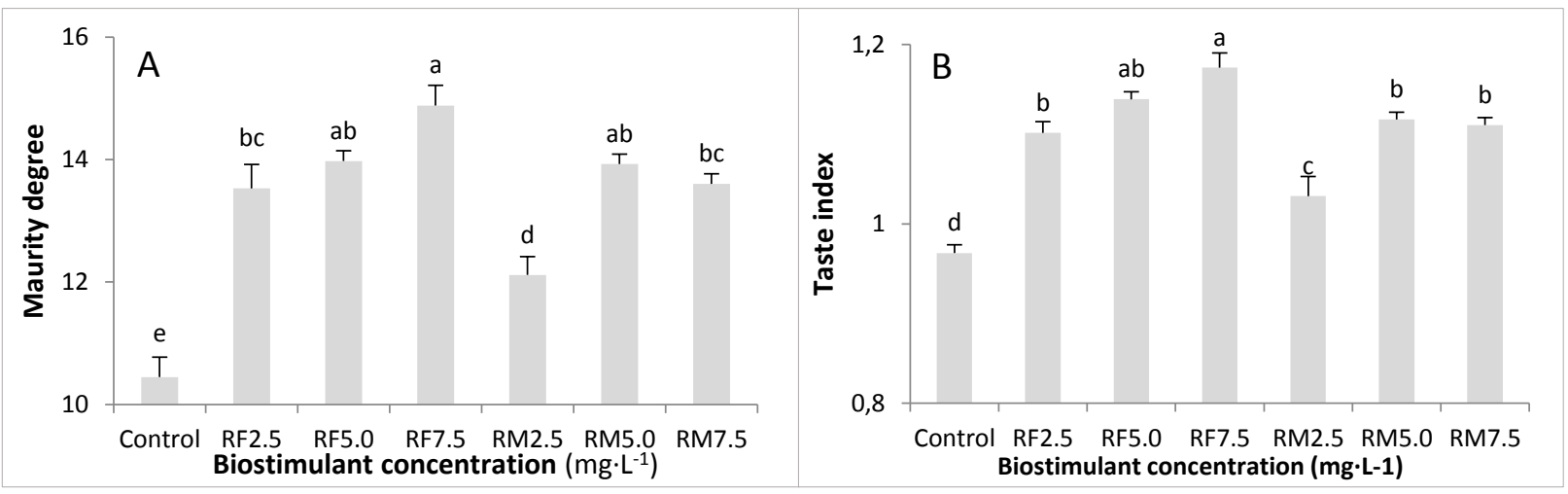

Figure 5. Maturity degree (A) and taste index of tomato fruits hybrid cultivar 'Merlice' (B), applied with two biostimulants under hydroponic system. The different lower case letters indicate significant differences between the treatments at $\mathrm{p}<0.05$ established by Tukey's multiple range test; values represent means $\pm \mathrm{SD}$ 


\section{DISCUSSION}

The application of biostimulants positively impacts plant growth by enhancing metabolism and modification of biochemical processes. Both biostimulants used in our experiment contain several compounds beneficial for the growth and yield of plants. RutfarmMaxifol contains polysaccharides, polyunsaturated fatty acids, enzymes, bioactive peptides, and free amino acids. Radifarm contains amino acids, glycosides, saponins, betaines, polysaccharides, organic acids, vitamins, and microelements. All of them are important for plants' growth and fruiting. A wide range of beneficial effects of using seaweed extract on plants was reported, including improved germination of seeds, increased yield and yield quality, and improved postharvest shelf life of fruits (Norrie \& Keathley 2006). Rayorath et al. (2008) reported that seaweed extracts enhanced root growth of Arabidopsis thaliana at very low concentrations $\left(0.1 \mathrm{~g} \cdot \mathrm{L}^{-1}\right)$. The positive results of the seaweed extract on tomato plants are attributed to its nutritional effects, parallel to their stimulative effects. Seaweed plays a positive role in seed germination and growth and development associated with hormonal effects (du Jardin 2015). In fact, known plant hormones and others compounds such as sterols and polyamines were identified in seaweed extracts (Craigie 2011). The increase in plant height, number of leaves, and fresh and dry biomass of tomato plants supplemented with biostimulants may be a synergy effect between its compounds and the resulting increase in endogenous levels of cytokinins and auxin, which can stimulate plant growth by affecting photosynthesis, respiration, and activation of plant defense systems, as was found in Kentucky bluegrass (Zhang et al. 2003).

Supplementation with biostimulants containing low-molecular-weight fractions exerts positive effects on plasma membrane functions (Nardi et al. 2002), which enables an increase in nutrient uptake (Chen \& Aviad 2015) by improving the root cell membrane permeability (Valdrighi et al. 1996), as in the present study can indirectly confirm the increase in root length (Fig. 1). RGR, CGR, and NAR were derived from these equations by tacitly assuming that plants' growth is a function of time. They represent the balance between metabolism and catabolism (Pereira \&
Machado 1987). According to Metcalf et al. (2006) and Rees et al. (2010), RGR and plant size are contradictory because of self-shading by the leaf canopy, increased allocation to structural components, and decreases in leaf area ratio (Philipson et al. 2012). Our experiment also showed that RGR declined with increasing plant size (Fig. 2A). As RGR is almost always a function of plant size, high values of RGR can occur either because plants are simply smaller or because they truly grow faster (Turnbull et al. 2008).

Biostimulant applications increased yield components compared to the control. This may be connected with the participation of these growth-stimulating hormones in different growth and development stages: pollen germination, fruit set, cell division, and elongation after pollination. Generally, the final yield $(\mathrm{kg}$ per plant) showed an increase of values in all the parameters in treatments with biostimulator applications. The yield was significantly affected by biostimulant concentrations (Abdelkader et al. 2019b; Francesca et al. 2020).

The effect of biostimulant on photosynthesis and secondary metabolism may also enhance the quality of tomato fruit (Colla et al. 2017) by increasing TSS and carotenoid contents. Overall, the main effect of biostimulants is to induce physiological responses in the treated plants, and most of these responses are able to affect plant metabolism, growth, and development (Wally et al. 2013a, b). The content of ascorbic acid in tomatoes is regulated by agriculture practices and environmental conditions (Zushi et al. 2020).

Radifarm treatments highly increased nitrate concentration compared to the other treatments ( $13 \%$ and $14 \%$ over control). The content of nitrates in tomato fruits can increase depending on various parameters associated with the plant and the environment, such as genotype, maturity, temperature, and nutrition (Abdelkader \& Puchkov 2019). According to WHO, adults consume between 20 and $70 \mathrm{mg}$ nitrate daily, and the maximum safe amount of nitrate daily entering the human body should be less than $3.65 \mathrm{mg} \cdot \mathrm{kg}^{-1}$ (EFSA 2008).

\section{CONCLUSIONS}

Biostimulants RutfarmMaxifol and Radifarm applied at three phases - for seed soaking and twice foliarly on the plants of tomato hybrid cultivar 'Merlice' grown under a hydroponic system increased several growth and fruit the parameters. 
All concentrations: $2.5,5.0$, and $7.5 \mathrm{mg} \cdot \mathrm{L}^{-1}$ of biostimulants, were beneficial and usually the highest concentration was the most effective. Radifarm had a more positive effect on tomato fruits' quality and RutfarmMaxifol on the growth and yield parameters.

\section{REFERENCES}

Abdelkader M.M., Puchkov M.Yu. 2019. Effect of growth regulators on productivity and quality of tomato crop under Volga delta conditions. Vegetable Crops of Russia 6: 36-40. DOI: 10.18619/20729146-2019-6-36-40.

Abdelkader M.M.M., Suliman A., Puchkov M., Loktionova E. 2019a. Applying a digital method for measuring leaf area index of tomato plants. Advances in Intelligent Systems Research 167: 5-8. DOI: 10.2991/ispc-19.2019.2.

Abdelkader M.M., Puchkov M.Y., Lysakov M.A., Loktionova E.G., Suliman A.A. 2019b. Effect of crezacin and humic acid on growth and physiological aspects of tomato plants (Lycopersicon esculentum). Journal of Applied Horticulture 21(1): 61-66. DOI: 10.2991/ispc-19.2019.2.

Bulgari R., Franzoni G., Ferrante A. 2019. Biostimulants application in horticultural crops under abiotic stress conditions. Agronomy 9(6); 306; 30 p. DOI: 10.3390/agronomy9060306.

Carvalho M.E.A., de Camargo e Castro P.R. 2019. Seaweeds as plant biostimulants. In: Pereira L., Bahcevandziev K., Joshi N.H. (Eds.), Seaweeds as Plant Fertilizer, Agricultural Biostimulants and Animal Fodder. CRC Press, pp. 80-99. DOI: 10.1201/9780429487156-5.

Chen Y., Aviad T. 2015. Effects of humic substances on plant growth. In: MacCarthy P., Clapp C.E., Malcolm R.L., Bloom P.R. (Eds.), Humic Substances in Soil and Crop Sciences: Selected Readings. ASA, pp. 161186. DOI: 10.2136/1990.humicsubstances.c7.

Colla G., Cardarelli M., Bonini P., Rouphael Y. 2017. Foliar applications of protein hydrolysate, plant and seaweed extracts increase yield but differentially modulate fruit quality of greenhouse tomato. HortScience 52(9): 1214-1220. DOI: 10.21273/hortsci12200-17.

Considine G.D. (Ed.) 2005. Van Nostrand's Encyclopedia of Chemistry, 5th ed. Association of Official Analytical Chemists. John Wiley \& Sons, $1856 \mathrm{p}$. DOI: $10.1002 / 0471740039 . v e c 0284$.

Corell M., Martín-Palomo M.J., Sánchez-Bravo P., Carrillo T., Collado J., Hernández-García F. et al. 2019. Evaluation of growers' efforts to improve the sustainability of olive orchards: Development of the hydroSOStainable index. Scientia Horticulturae 257; 108661; 9 p. DOI: 10.1016/j.scienta.2019.108661.
Craigie J.S. 2011. Seaweed extract stimuli in plant science and agriculture. Journal of Applied Phycology 23(3): 371-393. DOI: 10.1007/s10811-010-9560-4.

EFSA 2008. Nitrate in vegetables. Scientific Opinion of the Panel on Contaminants in the Food chain. European Food Safety Authority. EFSA Journal 6(6); 689; 79 p. DOI: 10.2903/j.efsa.2008.689.

Fereres E., Villalobos F.J. 2016. Agriculture and agricultural systems. In: Villalobos F.J., Fereres E. (Eds.), Principles of Agronomy for Sustainable Agriculture. Springer, Switzerland, pp. 1-12. DOI: 10.1007/978-3-319-46116-8_1.

Francesca S., Arena C., Mele B.H., Schettini C., Ambrosino P., Barone A., Rigano M.M. 2020. The use of a plant-based biostimulant improves plant performances and fruit quality in tomato plants grown at elevated temperatures. Agronomy 10(3); 363; 14 p. DOI: $10.3390 /$ agronomy 10030363.

du Jardin P. 2015. Plant biostimulants: Definition, concept, main categories and regulation. Scientia Horticulturae 196: 3-14. DOI: 10.1016/j.scienta.2015.09.021.

Metcalf C.J.E., Rees M., Alexander J.M., Rose K. 2006. Growth-survival trade-offs and allometries in rosette-forming perennials. Functional Ecology 20(2): 217-225. DOI: 10.1111/j.1365-2435.2006.01084.x.

Mohammed M., Wilson L.A., Gomes P.I. 1999. Postharvest sensory and physiochemical attributes of processing and nonprocessing tomato cultivars. Journal of Food Quality 22(2): 167-182. DOI: 10.1111/j.1745-4557.1999.tb00549.x.

Nardi S., Pizzeghello D., Muscolo A., Vianello A. 2002. Physiological effects of humic substances on higher plants. Soil Biology and Biochemistry 34(11): 1527-1536. DOI: 10.1016/s0038-0717(02)00174-8.

Navez B, Letard M, Grasselly D., Jost M. 1999. Les critères de qualité de la tomate. Infos CTIFL 155: 41-47.

Norrie J., Keathley J.P. 2006 Benefits of Ascophyllum nodosum marine-plant extract applications to 'Thompson Seedless' grape production. Acta Horticulturae 727: 243-247. DOI: 10.17660/actahortic.2006.727.27.

Okolie C.L., Mason B., Critchley A.T. 2018. Seaweeds as a source of proteins for use in pharmaceuticals and high-value applications. In: Hayes M. (Ed.), Novel Proteins for Food, Pharmaceuticals, and Agriculture. John Wiley \& Sons, pp. 217-238. DOI: 10.1002/9781119385332.ch11.

Van Oosten M.J., Pepe O., De Pascale S., Silletti S., Maggio A. 2017. The role of biostimulants and bioeffectors as alleviators of abiotic stress in crop plants. Chemical and Biological Technologies in Agriculture $4 ; 5 ; 12$ p. DOI: 10.1186/s40538-017-0089-5.

Parađiković N., Teklić T., Zeljković S., Lisjak M., Špoljarević M. 2019. Biostimulants research in some horticultural plant species - A review. Food and Energy Security 8(2); e00162, 17 p. DOI: 10.1002/fes3.162. 
Pereira A.R., Machado E.C. 1987. Análise quantitativa do crescimento de comunidades vegetais. Instituto Agronômico de Campinas, Brasil. Boletim Técnico $114 ; 33 \mathrm{p}$.

Philipson C.D., Saner P., Marthews T.R., Nilus R., Reynolds G., Turnbull L.A., Hector A. 2012. Light-based regeneration niches: Evidence from 21 dipterocarp species using size - specific RGRs. Biotropica 44(5): 627-636. DOI: 10.1111/j.1744-7429.2011.00833.x.

Rayorath P., Jithesh M.N., Farid A., Khan W., Palanisamy R., Hankins S.D. et al. 2008. Rapid bioassays to evaluate the plant growth promoting activity of Ascophyllum nodosum (L.) Le Jol. using a model plant, Arabidopsis thaliana (L.) Heynh. Journal of Applied Phycology 20: 423-429. DOI: 10.1007/s10811-007-9280-6.

Rees M., Osborne C.P., Woodward F.I., Hulme S.P., Turnbull L.A., Taylor S.H. 2010. Partitioning the components of relative growth rate: How important is plant size variation? American Naturalist 176(6): E152-E161. DOI: 10.1086/657037.

Robertson G.P., Harwood R.R. 2013. Agriculture, Sustainable. In: Levin S.A. (Ed.), Encyclopedia of Biodiversity, 2nd ed. Academic Press, pp. 111-118. DOI: 10.1016/b978-0-12-384719-5.00287-2.

Shukla P.S., Borza T., Critchley A.T., Prithiviraj B. 2016. Carrageenans from red seaweeds as promoters of growth and elicitors of defense response in plants. Frontiers in Marine Science 3; article 81; 9 p. DOI: 10.3389/fmars.2016.00081.

Shukla P.S., Borza T., Critchley A.T., Hiltz D., Norrie J., Prithiviraj B. 2018. Ascophyllum nodosum extract mitigates salinity stress in Arabidopsis thaliana by modulating the expression of miRNA involved in stress tolerance and nutrient acquisition. PLoS ONE 13(10); e0206221; 25 p. DOI: 10.1371/journal.pone.0206221.

Shukla P.S., Mantin E.G., Adil M., Bajpai S., Critchley A.T., Prithiviraj B. 2019. Ascophyllum nodosum-based biostimulants: Sustainable applications in agriculture for the stimulation of plant growth, stress tolerance, and disease management. Frontiers in Plant Science 10; article 655; 22 p. DOI: 10.3389/fpls.2019.00655.

Tkalec M., Vinković T., Baličević R., Parađiković N. 2010. Influence of biostimulants on growth and development of bell pepper (Capsicum annuиm L.). Acta Agriculturae Serbica 15(29): 83-88.

Turnbull L.A., Paul-Victor C., Schmid B., Purves D.W. 2008. Growth rates, seed size, and physiology: Do small-seeded species really grow faster? Ecology 89(5): 1352-1363. DOI: 10.1890/07-1531.1.

Usuda H. 2004. Evaluation of the effect of photosynthesis on biomass production with simultaneous analysis of growth and continuous monitoring of $\mathrm{CO}_{2}$ exchange in the whole plants of radish, cv Kosena under ambient and elevated $\mathrm{CO}_{2}$. Plant Production Science 7(4): 386-396. DOI: 10.1626/pps.7.386.

Valdrighi M.M., Pera A., Agnolucci M., Frassinetti S., Lunardi D., Vallini G. 1996. Effects of compost-derived humic acids on vegetable biomass production and microbial growth within a plant (Cichorium intybus)-soil system: a comparative study. Agriculture, Ecosystems and Environment 58(2-3): 133144. DOI: 10.1016/0167-8809(96)01031-6.

Wally O.S.D., Critchley A.T., Hiltz D., Craigie J.S., Han X., Zaharia L.I. et al. 2013a. Regulation of phytohormone biosynthesis and accumulation in Arabidopsis following treatment with commercial extract from the marine macroalga Ascophyllum nodosum. Journal of Plant Growth Regulation 32(2): 324-339. DOI: 10.1007/s00344-012-9301-9.

Wally O.S.D., Critchley A.T., Hiltz D., Craigie J.S., Han X., Zaharia L.I. et al. 2013b. Erratum to: Regulation of phytohormone biosynthesis and accumulation in Arabidopsis following treatment with commercial extract from the marine macroalga Ascophyllum nodosum. Journal of Plant Growth Regulation 32(2): 340-341. DOI: 10.1007/s00344-012-9311-7.

Yakhin O.I., Lubyanov A.A., Yakhin I.A., Brown P.H. 2017. Biostimulants in plant science: A global perspective. Frontiers in Plant Science 7; article 2049; 32 p. DOI: 10.3389/fpls.2016.02049.

Zeljković S.B., Parađiković N.A., Babić T.S., Đurić G.D., Oljača R.M., Vinković T.M., Tkalec M.B. 2010. Influence of biostimulant and substrate volume on root growth and development of scarlet sage (Salvia splendens L.) transplants. Journal of Agricultural Sciences 55(1): 29-36. DOI: 10.2298/jas1001029z.

Zhang X., Ervin E.H., Schmidt R.E. 2003. Plant growth regulators can enhance the recovery of Kentucky bluegrass sod from heat injury. Crop Science 43: 952-956. DOI: 10.2135/cropsci2003.0952.

Zushi K., Suehara C., Shirai M. 2020. Effect of light intensity and wavelengths on ascorbic acid content and the antioxidant system in tomato fruit grown in vitro. Scientia Horticulturae 274; 109673; 7 p. DOI: 10.1016/j.scienta.2020.109673. 